\title{
THE ENERGY-BALANCE STRUCTURE OF THE ANT ARCTIC ICE SHEET/ATMOSPHERE SYSTEM AS AN INDEX OF ANTARCTIC GLACIATION*
}

\author{
By V. G. Aver'yanov \\ (Arkticheskiy i Antarkticheskiy Nauchno-Issledovatel'skiy Institut, 34 Fontanka, Leningrad \\ 191104, U.S.S.R.)
}

\begin{abstract}
Mean multi-year values of the components of external mass and energy exchange in the ice sheet, moisture, radiation, and heat balances in the system Antarctic ice sheet/atmosphere have been estimated by various methods.

The major features of the above-mentioned balances have been determined as absolute and relative values. For the moisture balance, income of advective moisture is equal to $100 \%$; loss due to accumulation of moisture in the ice sheet is $83 \%$, due to sink into the atmosphere is $15 \%$, and sink from the ice sheet surface is $2 \%$. As for the radiation balance it has been found that income due to radiation at the top of the atmosphere and absorbed by the atmosphere long-wave radiation are $57 \%$ and $43 \%$, respectively; loss due to reflected short-wave radiation is $35 \%$, atmospheric long-wave radiation is $78 \%$, and net outgoing radiation from the surface is $9 \%$. Heat budget components have been found as follows: income due to absorbed short-wave radiation is $49 \%$, advection of heat is $40 \%$, and latent heat from phase transition of advective moisture is $11 \%$; loss due to outgoing long-wave radiation is $98 \%$, heat from phase transition of atmospheric moisture is $2 \%$.

The Antarctic ice sheet is a vast area of heat sink. Constant negative surface radiation balance and low temperature of the ice sheet suggest that the latter will exist at any small amount of precipitation and, therefore. current glaciation of Antarctica is rather stable.
\end{abstract}

RÉsumÉ. Structure du bilan de l'énergie du système calotte glaciaire Antarctique/atmosphère. On a estimé par différentes méthodes les valeurs moyennes sur plusieurs années des composantes des échanges extérieurs de masse et d'énergie dans la platforme glaciaire, humidité, radiation, et bilans thermiques, dans le systeme calotte glaciaire Antarctique/atmosphère.

Les traits principaux des bilans ci-dessus ont été déterminés en valeurs relatives et absolues. Pour le bilan d'humidité les apports d'humidite par advection sont de $100 \%$; la perte due à l'accumulation d'humidité sur la calotte glaciaire est de $83 \%$, celle due à l'évaporation dans l'atmosphère est de $15 \%$ et à l'évaporation depuis la calotte glaciaire de $2 \%$. Pour le bilan radiatif on a trouvé que les apports dus aux radiations reçues de la haute atmosphère et l'absorption de rayonnement de grande longueur d'onde par l'atmosphère sont respectivement de $57 \%$ et $43 \%$, la perte due aux rayonnements réfléchis de courte longueur d'onde est de $35 \%$, celle due au rayonnement atmosphérique de grande longueur d'onde est de $78 \%$, et la perte nette en radiation issue de la surface est de $9 \%$. Les composants du bilan thermique sont les suivants: l'apport dû à l'absorption de rayonnement de courte longueur d'onde est de $49 \%$, l'advection de chaleur sensible de $40 \%$ et la chaleur latente due à la transformation de l'humidité apporté par advection est de $11 \%$. La perte due au départ de rayonnement de grande longueur d'onde est de $98 \%$, celle due à la chaleur issue des changements d'etat de l'humidité atmosphérique de $2 \%$.

La calotte glaciaire Antarctique est une vaste zone de perte de chaleur. Le bilan radiatif de surface constamment négatif et la basse température de la calotte font croire que cette basse température existera quel que soit le faible taux de précipitation et que, par conséquent, la glaciation actuelle de l'Antarctique est assez stable.

Zusammenfassung. Die Struktur der Energiebilanz im System antarktischer Eisschild/Atmosphäre. Mit verschiedenen Methoden wurden Mittelwerte über mehrere Jahre der Komponenten des äusseren Massen- und Energieaustausches im Eisschild, der Feuchte, der Strahlung und der Wärmebilanz im System antarktischer Eisschild-Atmosphäre abgeschätzt.

* Revised version of a paper presented at the third International Symposium on Antarctic Glaciology, Columbus. Ohio, U.S.A., 7-12 September 1981. 
Die Hauptfaktoren der genannten Bilanzen wurden als Absolut- und Relativwerte bestimmt. Bei der Feuchtebilanz beträgt die Aufnahme advektiver Feuchte 100\%; der Verlust infolge der Feuchteakkumulation im Eisschild ist 83\%; in die Atmosphäre gehen 15\% und von der Oberfläche des Eisschildes $2 \%$ verloren. Bei der Strahlungsbilanz ergab sich ein Verlust von $43 \%$ der langwelligen Strahlung durch Absorption in der Atmosphäre; die kurzwellige Strahlung wird zu 35\% reflektiert, die langwellige Strahlung aus der Atmosphäre beträgt $78 \%$, die Nettostrahlung von der Oberfläche $9 \%$. Für die Komponenten des Wärmehaushalts ergaben sich folgende Werte: Aufnahme durch Absorption der kurzwelligen Strahlung 49\%, durch Advektion 40\% und als latente Wärme aus dem Phasenwechsel advektiver Feuchte 11\%; Abgabe durch langwellige Ausstrahlung 98\%, durch Phasenwechsel atmosphärischer Feuchte 2\%.

Der antarktische Eisschild ist ein riesiges Gebiet mit Wärmeverlust. Konstant negative Bilanzen der Oberflächenstrahlung und tiefe Temperaturen des Eisschildes lassen annehmen, dass dieser auch bei noch so geringen Niederschlagsmengen erhalten bleibt und die derzeitige Vereisung der Antarktis deshalb sehr stabil ist.

THE energy balance of the Antarctic ice sheet/atmosphere system appears to be the net result of interactions between the ice active layer and the atmosphere over a certain time period. This energy balance characterizes different amounts of heat and moisture participating in a complex process of glaciation. Recent fragmentary data on the marginal heat exchange are used to derive quantitative estimates of energy processes in the ice/atmosphere system by traditional geographical methods. All balance components were calculated for a closed balance, assuming that:

(i) The mass of the ice sheet is stable, i.e. iceberg calving is balanced by accumulation (Shumskiy, 1969);

(ii) The ice/atmosphere system is in thermal equilibrium, that is the algebraic sum of the heat input and losses should be equal to zero;

(iii) The mean annual heat exchange through the ice surface should be zero; during cold months the active ice layer loses the same amount of heat as it receives during warm months (Rusin, 1961; Rubin, 1962).

The moisture balance of the ice surface (mass exchange through the surface), of the atmosphere, and of the ice/atmosphere system can be described by the following expressions (UNESCO, 1978):

$$
\begin{aligned}
& r=A+E+q+f, \\
& a=r+c-E, \\
& a=c+A+q+f,
\end{aligned}
$$

where $r$ is the atmospheric precipitation made up of advective precipitation $r_{\mathrm{a}}$ and precipitation due to evaporation/condensation, or local precipitation, $r_{\mathrm{E}}\left(r=r_{\mathrm{a}}+r_{\mathrm{E}}\right), A$ the solid precipitation accumulated at the ice surface, it balances the iceberg calving, $E$ the evaporation from the surface, $q$ the wind-induced snow-drift from ice onto the ocean, $f$ the melt run-off from the ice surface into the ocean, $a$ the moisture advection to the atmosphere, and $c$ the total atmospheric moisture flux over the ice surface comprised of the transient advective moisture $c^{\prime}$ and local moisture discharge $c^{\prime \prime}\left(c=c^{\prime}+c^{\prime \prime}\right)$, where

$$
c^{\prime}=a-r_{\mathrm{a}}, \quad c^{\prime \prime}=E-r_{\mathrm{E}} .
$$

Mean annual accumulation over the whole Antarctic ice sheet was calculated from the map constructed by Kotlyakov and others (1977), the melt water run-off from the surface of the marginal glaciers was calculated by Klokov (1979), the value of the wind-driven snow-drift to the ocean was calculated from the results of a few direct measurements of snow-drift made in 
Antarctica during various expeditions (Aver'yanov, 1980). The first estimates of the surface evaporation from the whole continental ice sheet were made. The minimum values of direct measurements and calculations for various glaciomorphological zones such as ice shelves, coastal areas, slopes of glaciers with absolute height of $1000-2500 \mathrm{~m}$ as well as high plateaux were used for these estimations (Aver'yanov, 1980).

The total moisture advection in the atmosphere was calculated by Drozdov and Grigor'yeva (1963) using the formula

$$
a=w \bar{u} l N
$$

where $w$ is the atmospheric moisture content equal to $2.52 \mathrm{~mm}$ (Voskresenskiy, 1976), $\bar{u}$ the mean speed of effective moisture transfer equal to $8.9 \mathrm{~m} \mathrm{~s}^{-1}$ (Voskresenskiy, 1976), $l$ the linear dimensions of the area equal to $\sqrt{ } S$ where $S=13.94 \times 10^{6} \mathrm{~km}^{2}$, and $N$ the number of seconds in the period of calculation. The total atmospheric moisture discharge is determined from Equations (2) and (3). The author in his earlier work presented numerical values of the balance components and the scheme of Antarctic moisture turn-over (Aver'yanov, 1979[a]). Mean annual specific values of mass exchange components of the ice surface and of atmospheric moisture exchange together with their thermal equivalents are shown in Table I.

The mean annual heat balance of the ice-sheet surface, the atmosphere, and the ice/atmosphere system is expressed by the following expressions. They apply to the whole area of Antarctic glacierization.

$$
\begin{gathered}
R+(L E)+P=0, \\
R_{\mathrm{a}}+(L r)+P+(A d)=0, \\
R_{\mathrm{s}}+(L a)+(L c)+(A d)=0,
\end{gathered}
$$

where $R$ is the radiation balance of the ice surface, $R_{\mathrm{a}}$ the radiation balance of the atmosphere,

TABle I. Mean annual values of mass exchange components for the iCE SHEET SURFACE AND THOSE OF MOISTURE TURNOVER IN THE ANTARCTIC ATMOSPHERE TOGETHER WITH THEIR THERMAL EQUIVALENTS (LATENT HEAT OF WATER-PHASE TRANSFORMATIONS)

\section{Components}

1. Advective moisture, $a$

2. Atmospheric precipitation, $r$

3. Advective precipitation, $r_{\mathrm{a}}$

4. Local precipitation, $r_{\mathrm{E}}$

5. Atmospheric moisture discharge, $c$

6. Moisture transfer, $c^{\prime}$

7. Moisture discharge due to evaporation, $c^{\prime \prime}$

8. Surface accumulation, $A$

9. Surface evaporation, $E$

10. Wind-driven snow drift, $q$

11. Liquid discharge from the surface, $f$

\begin{tabular}{rlc} 
& \multicolumn{2}{c}{ Thermal equivalent } \\
$\mathrm{kg} / \mathrm{m}^{2}$ & Symbol & $\mathrm{W} / \mathrm{m}^{2}$ \\
190 & $(L a)$ & 17 \\
181 & $(L r)$ & 16 \\
176 & $\left(L r_{\mathrm{a}}\right)$ & 15 \\
5 & $\left(L r_{\mathrm{E}}\right)$ & 1 \\
29 & $(L c)$ & 3 \\
14 & $\left(L c^{\prime}\right)$ & 2 \\
15 & $\left(L c^{\prime \prime}\right)$ & 1 \\
158 & $(L A)$ & 14 \\
20 & $(L E)$ & 2 \\
2 & $(L q)$ & 0.2 \\
1 & $\left(L{ }_{1} f\right)$ & 0.01
\end{tabular}

Note: The values for 1, 3, 4, 5, 6, 7 are from Aver'yanov (1979[a]) and those for 2, 8, 9, 10, 11, from Aver'yanov (1980).

$L$-latent heat of evaporation (sublimation) equal to $2.84 \mathrm{MJ} / \mathrm{kg}$.

$L_{1}$-latent heat of melting equal to $0.34 \mathrm{MJ} / \mathrm{kg}$. 
$R_{\mathrm{s}}$ the radiation balance of the ice-atmosphere system, $(L E)$ the latent heat of evaporation, $(\mathrm{Lr})$ the latent heat of precipitation, $(L a)$ the latent heat of phase transformations of advective moisture, $(L c)$ the latent heat of phase transformation of the atmospheric moisture discharge, $P$ the turbulent heat exchange between the ice surface and atmosphere, and $(A d)$ the heat advection in the atmosphere.

To reduce the heat-balance calculations on the basis of the available solar radiation data the following radiation balance equations are used

$$
\begin{gathered}
R=R_{\mathrm{k}}-E_{0}, \\
R_{\mathrm{a}}=I_{\mathrm{a}}-\left(E_{\infty}-E_{0}\right), \\
R_{\mathrm{s}}=\left(R_{\mathrm{k}}+I_{\mathrm{a}}\right)-E_{\infty},
\end{gathered}
$$

where $R_{\mathrm{k}}$ is the short-wave radiation absorbed by the surface, $I_{\mathrm{a}}$ the short-wave radiation absorbed by the atmosphere, $E_{0}$ the effective surface radiation, $\left(E_{\infty}-E_{0}\right)$ the atmospheric radiation into space, and $E_{\infty}$ the long-wave radiation into space. It follows that

$$
R_{\mathrm{s}}=R+R_{\mathrm{a}} .
$$

The absorbed short-wave radiation is calculated from the formula:

$$
R_{\mathrm{k}}=Q(1-\alpha)
$$

where $Q$ is the total radiation coming to the surface, $\alpha$ is the surface albedo, and

$$
I_{\mathrm{a}}=\left(R_{\mathrm{k}}+I_{\mathrm{a}}\right)-R_{\mathrm{k}}
$$

where $\left(R_{\mathrm{k}}+I_{\mathrm{a}}\right)$ is the short-wave radiation absorbed by the ice/atmosphere system.

Solar radiation coming to the atmosphere $Q_{\mathrm{s}}$ is given by

$$
Q_{\mathrm{s}}=\frac{\left(R_{\mathrm{k}}+I_{\mathrm{a}}\right)}{1-\alpha_{\mathrm{s}}}
$$

where $\alpha_{\mathrm{s}}$ is the albedo of the ice/atmosphere system.

New maps of the distribution of annual fluxes of total radiation $Q$ and the ice-surface radiation balance $R$ in Antarctica (Marshunova, 1980) together with the long-term surface radiation data from Antarctic stations (Dolgin and others, 1976) were used as initial data for the calculations of the radiation-balance components.

Another important source of information on the heat exchange between the Antarctic ice sheet and the atmosphere is the Nimbus- 3 results and the calculations of the solar radiation fluxes and long-wave radiation based on the satellite data (Raschke and others, 1973). The results of the calculations are presented on maps of the South Polar region as mean annual albedo $\alpha_{\mathrm{s}}$, absorbed short-wave $\left(R_{\mathrm{k}}+I_{\mathrm{a}}\right)$ and outgoing long-wave radiation $E_{\infty}$, and radiation balance $R_{\mathrm{s}}$ of the ice/atmosphere system. The numerical values of the radiation balance components for Antarctica have been published by the author (Aver'yanov, 1979[b]).

The usual difficulties due to the lack of the necessary amount of data of instrumental measurements arise when attempts are made to determine long-wave radiation fluxes described by the following equations.

The surface long-wave radiation balance is given by

$$
E_{0}=E_{\mathrm{a}}-E_{\mathrm{z}}
$$


where $E_{0}$ is the effective radiation of the surface calculated by Equation (8) in which $R$ and $R_{\mathrm{k}}$ are measured variables (Dolgin and others, 1976; Marshunova, 1980), $E_{\mathrm{z}}$ is the surface radiation calculated by the Stefan-Boltzmann formula $E_{z}=\delta \sigma T^{4}$ for $T=237.7 \mathrm{~K}$ which is equal to the mean annual temperature of the ice surface (Shumskiy, 1969), and $E_{\mathrm{a}}$ is the atmospheric counter-radiation defined as $E_{0}+E_{\mathbf{z}}$.

The long-wave radiation balance of the atmosphere is given by

$$
E^{\prime}=E_{\mathrm{k}}-E_{\mathrm{a}}-\left(E_{\infty}-E_{0}\right)
$$

where $\left(E_{\infty}-E_{0}\right)$ is the atmospheric radiation into space, $E_{\infty}$ being a measured variable (Raschke and others, 1973), and $E_{\mathrm{k}}$ is the absorption by the atmosphere equal to $E_{\mathrm{z}}-E_{\mathrm{w}}$ where $E_{\mathrm{w}}$ is that part of the ice surface radiation outgoing into space.

It is known that most of the ice surface radiation is absorbed by atmospheric water vapour, $\mathrm{CO}_{2}$, and ozone, but mainly by the water vapour which is transparent to infra-red radiation only in a narrow spectral band known as the atmospheric window. We do not know yet the amount of heat $E_{\mathrm{w}}$ outgoing through that window in Antarctica. To close the long-wave radiation balance we can assume this part of the radiation outgoing into space to be approximately numerically equal to the effective ice surface radiation $E_{0}$ (in fact it can be a little lower), i.e. $E_{\mathrm{w}}=E_{0}$. Then

TABLE II. COMPONENTS OF RADIATION AND HEAT BALANCE

Balance components
Radiation balance

A. Short-wave radiation

Coming to the atmosphere, $Q_{\text {s }}$

Coming to the Earth's surface, $Q$

Reflected by the Earth's surface, $Q \alpha$

$\begin{array}{rr}195 & 100 \\ 133 & 68 \\ 109 & 56 \\ 10 & 5 \\ 119 & 61 \\ 24 & 12 \\ 52 & 27 \\ 76 & 39\end{array}$

Reflected by the top of the atmosphere, $Q_{s} \alpha^{\prime}$

Reflected by the system, $Q_{\mathrm{s}} \alpha_{\mathrm{s}}$

Absorbed by the surface, $R_{\mathrm{k}}$

Absorbed by the atmosphere, $I_{\mathrm{a}}$

Absorbed by the system, $R_{\mathrm{k}}+I_{\mathrm{a}}$

$180 \quad 92$

$B$. Long-wave radiation

Radiation from the surface, $E_{\mathrm{z}}$

Radiation from the atmosphere, $E_{\mathrm{a}}+\left(E_{\infty}-E_{0}\right)$

Counter-atmospheric radiation, $E_{\mathrm{a}}$

Absorption by the atmosphere, $E_{\mathrm{k}}$

Effective surface radiation, $E_{0}$

Atmospheric radiation into space, $E_{\infty}-E_{0}$

Outgoing radiation, $E_{\infty}$

\section{Net radiation}

of the surface, $R$

of the atmosphere, $R_{\mathrm{a}}$ of the system, $R_{\mathrm{s}}$

D. Thermal balance

Turbulent heat exchange, $P$

$\begin{array}{rr}10 & 5 \\ 66 & 34 \\ 76 & 39\end{array}$

Advective heat, $(A d)$

E. Albedo

Ice sheet surface, $\alpha=82 \% Q$

Antarctic atmosphere, $\alpha^{\prime}$

Ice sheet/atmosphere system, $\alpha_{s}$ 
the long-wave radiation absorbed by the atmosphere $E_{\mathrm{k}}$ would be equal to the atmospheric counter-radiation $E_{\mathrm{a}}$, through the nature of this coincidence is considered to be irregular. by

The balance of long-wave radiation in the ice surface/atmosphere system can be then given

$$
E_{\infty}=\left(E_{\infty}-E_{0}\right)+E_{\mathrm{w}}
$$

where $E_{\infty}$ is the instrumentally measured value (Raschke and others, 1973), $\left(E_{\infty}-E_{0}\right)$ is calculated as shown above, and $E_{\mathrm{w}}$ is taken from the consideration that $E_{\mathrm{w}}=E_{0}$.

Advective heat $(A d)$ and turbulent exchange $P$ are determined as residuals of Equations (5), (6), and (7). Table II shows the components of radiation and heat balance, obtained as described above.

The accuracy of absolute values in Tables I and II seems not to be very high due to errors caused by different measuring methods and paucity of observational data, because of this the data taken for averaging were not homogeneous in quality and time. This is primarily true for moisture parameters, while the radiation balance components in a number of cases were calculated with an accuracy comparable with the probable measuring error. These data, however, allow us to assess the order of magnitude of major heat and moisture fluxes participating in the Antarctic glacierization. They are also indicative of the structure of the moisture and heat balances.

\section{Moisture balance (Table III)}

Ninety-nine per cent of the total surface discharge $Q^{\prime}\left(Q^{\prime}=A+q+f\right)$ is the solid-phase moisture. Weak evaporation causes the discharge coefficient $Q^{\prime} / r(=0.89)$ to be much larger than

TABLE III. MOISTURE BALANCE

\begin{tabular}{|c|c|c|c|c|c|}
\hline \multicolumn{3}{|c|}{ Income } & \multicolumn{3}{|c|}{ Expenditure } \\
\hline Balance component & $\mathrm{kg} / \mathrm{m}^{2}$ year & $\%$ & Balance component & $\mathrm{g} / \mathrm{m}^{2}$ year & $\%$ \\
\hline \multicolumn{6}{|c|}{ SURFACE } \\
\hline \multirow[t]{4}{*}{ Atmospheric precipitation, $r$} & 181 & 100 & Accumulation, $A$ & 158 & 87 \\
\hline & & & Evaporation, $E$ & 20 & 11 \\
\hline & & & Wind-discharged snow, $q$ & 2 & 1 \\
\hline & & & Liquid discharge, $f$ & 1 & 1 \\
\hline \multirow[t]{2}{*}{ Total } & 181 & 100 & Total & 181 & 100 \\
\hline & \multicolumn{5}{|c|}{ ATMOSPHERE } \\
\hline \multirow{3}{*}{$\begin{array}{l}\text { Advective moisture, } a \\
\text { Evaporation from } \\
\text { the surface, } E\end{array}$} & 190 & 90 & Atmospheric precipitation, $r$ & 181 & 86 \\
\hline & & & Atmospheric liquid & & \\
\hline & 20 & 10 & discharge, $c$ & 29 & 14 \\
\hline \multirow[t]{2}{*}{ Total } & 210 & 100 & Total & 210 & 100 \\
\hline & & IEET/A & SPHERE SYSTEM & & \\
\hline \multirow[t]{6}{*}{ Moisture advection, $a$} & 190 & 100 & $\begin{array}{l}\text { Surface accumulation, } A \\
\text { Atmospheric liquid }\end{array}$ & 158 & 83 \\
\hline & & & $\begin{array}{l}\text { Atmospheric liquid } \\
\text { discharge, } c\end{array}$ & 29 & 15 \\
\hline & & & $\begin{array}{l}\text { Snow-drift from } \\
\text { the surface, } a\end{array}$ & & 1 \\
\hline & & & $\begin{array}{l}\text { the surface, } q \\
\text { Liquid discharge }\end{array}$ & 2 & 1 \\
\hline & & & from the surface, $f$ & 1 & 1 \\
\hline & 190 & 100 & Total & 190 & 100 \\
\hline
\end{tabular}


it is in the Arctic (0.70). The moisture turn-over coefficient $r / r_{\mathrm{a}}(=1.03)$ is lower than it is in African deserts, indicating that there is no local precipitation due to evaporation. The ratio of the total outflow of the atmospheric moisture to the precipitation amount $c / r(=0.16)$ indicates a relatively high intensity of precipitation formation processes and degree of usage of advective moisture. That is why the ratio of the total surface discharge to the atmospheric moisture outflow in Antarctica $Q^{\prime} / c$ is very large (5.6), it is 2.7 times larger than it is in Greenland. If we consider the fact that $83 \%$ of the advective moisture coming to the Antarctic mainland is stored in the Antarctic ice sheet, we can agree that it is the largest area of atmospheric moisture discharge on the Earth's surface. It is a well-known fact that the Antarctic ice sheet stores $90 \%$ of the fresh water available over the Earth's surface.

\section{Radiation balance (Table IV)}

The negative sign of the ice sheet radiation balance seems to be due to a very high reflectivity of the ice surface rather than a large effective radiation. The positive balance of the short-wave radiation is three to four times less than it is in those areas where there are nunataks.

Radiation measurements from Nimbus- 3 helped us to estimate the radiation balance of the Antarctic atmosphere (Raschke and others, 1973). It appears that the top of the atmosphere gets $12 \%$ more radiation than is predicted by theoretical calculations (Kondrat'yev, 1965; Budyko, 1971). The albedo of the atmosphere is very low due to its extreme transparency. The long-wave radiation of the atmosphere is $55 \%$ of the radiation directed to the surface of the Earth and $45 \%$ is the outgoing radiation from the top of the atmosphere, while for the Earth's atmosphere as a whole these fluxes are $70 \%$ and $30 \%$.

The ice surface/atmosphere system gets $57 \%$ of its radiation from the Sun and $43 \%$ is the long-wave radiation emitted from the ice surface and absorbed by the atmosphere. The radiation losses are as follows: reflected short-wave radiation is $28 \%$ and long-wave radiation lost to space is $72 \%$. This is explained by the very high albedo of the system resulting in a smaller flux of absorbed short-wave radiation in Antarctica which is 3.2 times less than elsewhere.

TABLE IV. RADiATION BALANCE

\begin{tabular}{|c|c|c|c|}
\hline \multirow{2}{*}{\multicolumn{4}{|c|}{ Expenditure }} \\
\hline & & & \\
\hline Radiation & $\mathrm{W} / \mathrm{m}^{2}$ & Radiation & $\mathrm{W} / \mathrm{m}^{2}$ \\
\hline \multicolumn{4}{|c|}{ SURFACE } \\
\hline $\begin{array}{l}\text { Incoming, short-wave, } Q \\
\text { Long-wave, counter-radiation of }\end{array}$ & 133 & Reflected, short-wave, $Q \alpha$ & 109 \\
\hline $\begin{array}{l}\text { Long-wave, counter-radiation of } \\
\text { the atmosphere, } E_{\mathrm{a}}\end{array}$ & & Long-wave, surface radiation, $E_{3}$ & \\
\hline Total & $\begin{array}{l}140 \\
279\end{array}$ & Total & 289 \\
\hline \multicolumn{4}{|c|}{ ATMOSPHERE } \\
\hline Incoming, short-wave, $Q_{\mathrm{s}}$ & 195 & Reflected, short-wave, $Q_{\mathrm{s}} \alpha^{\prime}$ & 10 \\
\hline Long-wave absorption, $E_{\mathrm{k}}$ & 146 & Short-wave, coming to the surface, $Q$ & 133 \\
\hline & & Long-wave radiation, $E_{\mathrm{a}}+\left(E_{\infty}-E_{0}\right)$ & 264 \\
\hline Total & 341 & Total & 407 \\
\hline \multicolumn{4}{|c|}{ SURFACE/ATMOSPHERE SYSTEM } \\
\hline Short-wave coming to the atmosphere, $Q_{\mathrm{s}}$ & 195 & Short-wave reflected, $Q_{s} \alpha_{s}$ & 119 \\
\hline Long-wave absorption, $E_{\mathrm{k}}$ & 146 & $\begin{array}{l}\text { Long-wave, atmospheric radiation, } \\
E_{\mathrm{a}}+\left(E_{\infty}-E_{0}\right)\end{array}$ & $\begin{array}{r}264 \\
34\end{array}$ \\
\hline Total & 341 & $\begin{array}{l}\text { Surface effective, } E_{0} \\
\text { Total }\end{array}$ & 417 \\
\hline
\end{tabular}


Table V. Heat balance

\begin{tabular}{|c|c|c|c|c|c|}
\hline Radiation & $\mathrm{W} / \mathrm{m}^{2}$ & $\%$ & Radiation & $\mathrm{W} / \mathrm{m}^{2}$ & \\
\hline \multicolumn{6}{|c|}{ SURFACE } \\
\hline Incoming short-wave, $Q$ & 133 & 46 & Reflected, short-wave, $Q \alpha$ & 109 & \\
\hline Long-wave, counter, $E_{\mathrm{a}}$ & 146 & 50 & Long-wave, surface, $E_{\mathrm{z}}$ & 180 & \\
\hline Turbulent heat exchange, $P$ & 12 & 4 & Latent evaporation heat, $(L E)$ & 2 & \\
\hline Total & 291 & 100 & Total & 291 & \\
\hline \multicolumn{6}{|c|}{ ATMOSPHERE } \\
\hline Incoming, short-wave, $Q_{\mathrm{s}}$ & 195 & 46 & Reflected, short-wave, $Q_{\mathrm{s}} \alpha^{\prime}$ & 10 & \\
\hline Long-wave absorption, $E_{\mathrm{k}}$ & 146 & 35 & Short-wave to the surface, $Q$ & 133 & \\
\hline Advective heat, $(A d)$ & 62 & 15 & Long-wave radiation, $E_{\mathrm{a}}+\left(E_{\infty}-E_{0}\right)$ & 264 & \\
\hline Latent heat of precipitation $(L r)$ & 16 & 4 & Turbulent heat exchange, $P$ & 12 & \\
\hline Total & 419 & 100 & Total & 419 & 10 \\
\hline \multicolumn{6}{|c|}{ ICE SHEET SURFACE/ATMOSPHERE } \\
\hline Incoming surface radiation, $Q_{\mathrm{s}}$ & 195 & 71 & Reflected, short-wave, $Q_{s} \alpha_{s}$ & 199 & \\
\hline Advective heat, $(A d)$ & 62 & 23 & Outgoing radiation, $E_{\infty}$ & 152 & \\
\hline Latent heat of moisture advection, $(\mathrm{La})$ & a) 17 & 6 & $\begin{array}{l}\text { Latent heat of atmospheric moisture } \\
\text { discharge, }(L C)\end{array}$ & 3 & \\
\hline Total & 274 & 100 & Total & 274 & 100 \\
\hline
\end{tabular}

\section{Heat balance (Table V)}

Antarctica is the only land area where the turbulent heat flux is directed from the atmosphere to the ice surface, that is the continent can be regarded as a huge heat sink. The turbulent heat flux is $33 \%$ of the solar flux absorbed by the ice surface.

Speaking of the heat coming to the atmosphere, we have to mention heat advection (which includes latent heat due to precipitation) which is 1.5 times higher than that of the absorbed short-wave radiation, provided the Earth's atmosphere gets equal amounts of advective and radiant heat.

In the ice/atmosphere system the heat income is equally represented by the absorption of short-wave radiation and by non-radiational exchanges, their relative amounts being $39 \%$ of the solar radiation coming to the top of the atmosphere. The expenditure of thermal energy in Antarctica is almost exclusively due to long-wave radiation from the ice surface and from the top of the atmosphere. The total loss of radiant energy caused by the negative radiation balance of the ice/atmosphere system related to the total area of the ice sheet $\left(13.94 \times 10^{6} \mathrm{~km}^{2}\right)$ per year is $3.3 \times 10^{13}$ GJ. It should be mentioned that a similar value was obtained by Rubin (1962) though he used another method.

Figure 1 shows the major heat fluxes participating in the energy exchange processes between the Antarctic ice sheet and the atmosphere, the flux values are given in per cent of the radiation

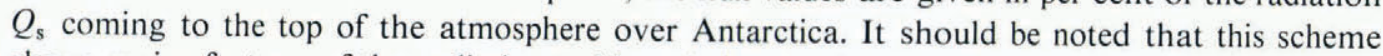
shows major features of the radiation and heat balances of Antarctica, however the components of radiation fluxes are not fully taken into account. For example, the short-wave radiation $I_{\mathrm{a}}$ absorbed by the atmosphere originates not only from the absorption of part of the radiation when flux $Q_{\text {s }}$ passes through the atmosphere to the ice surface, as the atmosphere also itself absorbs part of $Q \alpha$, the radiation reflected from the surface.

The glaciological significance of the thermal losses from the Antarctic ice sheet $\left(3.3 \times 10^{13} \mathrm{GJ}\right)$ and the corresponding heat from lower latitudes becomes evident when we compare this value with the changes of the heat content of the atmosphere caused by climatic 


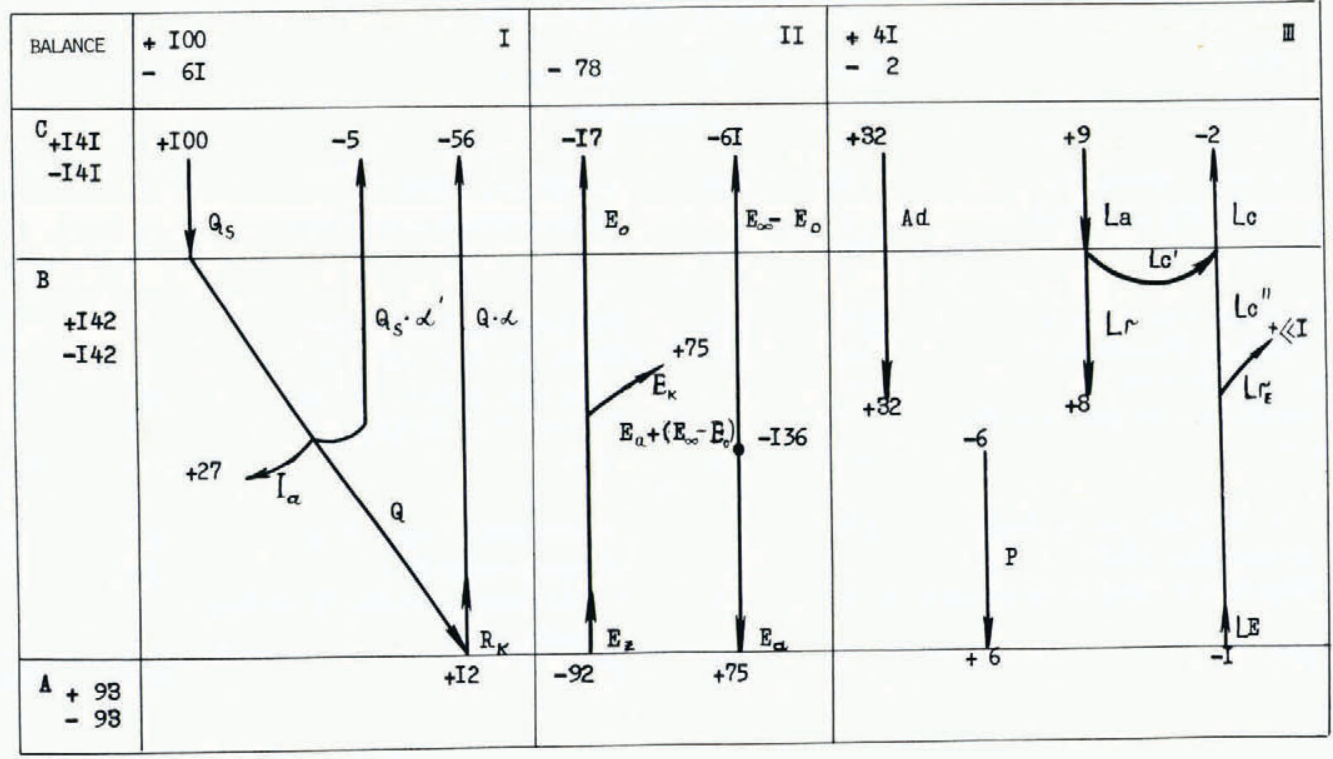

Fig. 1. The scheme of the thermal balance of Antarctica: $A$-the ice sheet surface, $B$-Antarctic atmosphere, $C$-ice surface/atmosphere system, I-short-wave radiation, II-long-wave radiation, III-non-radiational exchange. (Symbols are as in Tables $I$ and II).

temperature changes. The marginal heat losses exceed by two orders of magnitude the changes of heat content of the Antarctic atmosphere $\left(1.0 \times 10^{11} \mathrm{GJ}\right)$ and are an order of magnitude larger than the changes of the heat content of the whole of the Earth's atmosphere $\left(5.3 \times 10^{12} \mathrm{GJ}\right)$ if the temperature changes by $1 \mathrm{~K}$. Thus a contemporary climatic change could not trigger any qualitative changes of the Antarctic glacial climate.

The heat and moisture advection onto the ice sheet, the amount of atmospheric precipitation and accumulation, and the radiation balance are believed to be significant glacio-climatic indices of the Antarctic glacierization regime. The invariably negative radiation balance here determined results in such low temperatures of the ice surface that the glacier would maintain itself with the smallest possible amount of precipitation. This is confirmed by the position of the snow-line at sea-level beyond the ice sheet. Considering these natural features and the above-mentioned enormous inertia of the cold ice-covered mainland in response to any external forcing, we can believe the modern Antarctic glaciation to be steady with respect to presently occurring climatic change.

MS. received 11 September 1981 and in revised form 21 September 1982

\section{REFERENCES}

Aver'yanov, V. G. 1979[a]. Balans vlagi v sisteme "poverkhnost' lednikovogo pokrova Antarktidy-atmosfera" [Moisture balance in the system "Antarctic ice sheet surface and the atmosphere"|. Materialy. Glyatsiologicheskikh Issledovaniy. Khronika. Obsuzhdeniya, Vyp. 35, p. 209-11.

Aver'yanov, V. G. 1979[b]. Massoenergoobmen lednikovogo pokrova Antarktidy s atmosferoy [Mass and energy exchange of the ice sheet of Antarctica with the atmosphere]. Izvestiya Akademii Nauk SSSR. Serila Geograficheskaya, 1979, No. 1, p. 20-30. 
Aver'yanov, V. G. 1980. Otsenka sostavlyayushchikh massoobmena lednikovogo pokrova Antarktidy s atmosferoy |Evaluation of the mass exchange of components of the Antarctic ice sheet and the atmosphere|. Informatsionnyy Byulleten' Sovetskoy Antarkticheskoy Ekspeditsii, No. 100, p. 10-16.

Budyko, M. I. 1971. Klimat i zhizn' [Climate and life]. Leningrad, Gidrometeoizdat.

Dolgin, I. M., and others, ed. 1976. Spravochnik po klimatu Antarktidy. Tom I. Solnechnaya radiatsiya. radiatsionnyy balans, solnechnoye siyaniye |Handbook on the climate of Antarctica. Vol. I. Solar radiation, net radiation, sunshine]. [Edited by] I. M. Dolgin, M. S. Marshunova, L. S. Petrov. Leningrad, Gidrometeoizdat.

Drozdov, O. A., and Grigor'yeva, A. S. 1979. Vlagooborot $v$ atmosfere [Moisture turnover in the atmosphere]. Leningrad, Gidrometeoizdat.

Klokov, V. D. 1979. Tayaniye $i$ zhidkiy stok s poverkhnosti lednikovogo pokrova Antarktidy |Melting and liquid discharge from the Antarctic ice sheet]. Leningrad, Gidrometeoizdat.

Kondrat'yev, K. Ya. 1965. Aktinometriya [Actinometry]. Leningrad, Gidrometeoizdat.

Kotlyakov, V. M., and others. 1977. Ledovyy balans Antarktidy [The ice budget of Antarctica]. [By] V. M. Kotlyakov, K. S. Losev, I. A. Loseva. Izvestiya Akademii Nauk SSSR. Seriya Geograficheskaya, 1977, No. 1 p. $5-15$.

Marshunova, M. S. 1980. Usloviya formirovaniya i kharakteristiki radiatsionnogo klimata Antarktidy |Conditions of formation and characteristics of radiation climate of Antarctica]. Leningrad, Gidrometeoizdat.

Raschke, E., and others. 1973. The annual radiation balance of the earth-atmosphere system during $1969-70$ from Nimbus 3 measurements, [by] E. Raschke, T. H. Vonder Haar, W. R. Bandeen, and M. Pasternak. Journal of the Atmospheric Sciences, Vol. 30, No. 3, p. 341-64.

Rubin, M. J. 1962. Atmospheric advection and the Antarctic mass and heat budget. (In Wexler, H., and others, ed. Antarctic research: the Matthew Fontaine Maury memorial symposium. [Edited by] H. Wexler, M.J. Rubin, and J. E. Caskey, Jr. Washington, D.C., American Geophysical Union, p. 149-59. (Geophysical Monograph Series, No. 7.))

Rusin, N. P. 1961. Meteorologicheskiy i radiatsionnyy rezhim Antarktidy |Meteorological and radiation regime of Antarctica|. Leningrad, Gidrometeoizdat.

Shumskiy, P. A., and others. 1969. Oledeneniye Antarktidy |Ice cover of Antarctica|. |By| P. A. Shumskiy |and 5 others|. (In Tolstikov, Ye. 1., ed. Atlas Antarktiki. 2 |Atlas of the Antarctic. 2]. Leningrad, Gidrometeorologicheskoye Izdatel'stvo, p. 367-400.)

UNESCO. 1978. World water balance and water resources of the Earth. Leningrad, Hydrometeorological Publishing House. (UNESCO Studies and Reports in Hydrology, 25.)

Voskresenskiy, A. N. 1976. O vlagosodershanii $v$ atmosfere nad Antarktidoy [On the moisture content of the Antarctic atmosphere]. Trudy Arkticheskogo i Antarkticheskogo Nauchno-Issledovatel'skogo Instituta. Tom 327. p. $56-67$. 